\title{
Aktivitas Inhibisi Enzim Alfa-glukosidase dari Ekstrak Rimpang Bangle (Zingiber cassumunar Roxb.) secara In vitro
}

\author{
Ari Yuniarto, Nita Selifiana \\ Rumpun Bidang Ilmu Farmakologi, Sekolah Tinggi Farmasi Bandung \\ Korespondensi: Ari Yuniarto \\ Email: ariyuniarto@yahoo.co.id
}

\begin{abstract}
ABSTRAK: Diabetes mellitus merupakan penyakit kelainan metabolik yang ditandai dengan kondisi hiperglikemia. Salah satu obat yang dapat digunakan untuk menangani diabetes mellitus, khususnya untuk diabetes mellitus tipe II adalah akarbosa. Akarbosa dapat digunakan pada pasien dengan kadar gula post-prandial yang tinggi. Akarbosa bekerja dengan mekanisme menghambat aktivitas enzim alfa-glukosidase di dalam usus. Penghambatan yang terjadi pada enzim alfa-glukosidase menyebabkan penundaan absorpsi dan digesti glukosa. Maka, kenaikan kadar gula post-prandial dapat dicegah. Namun, penggunaan obat sintetik antidiabetes seperti akarbosa dalam jangka waktu panjang dapat memberikan beberapa efek samping, khususnya gangguan pada sistem saluran pencernaan. Oleh karena itu, penggunaan obat bahan alam sebagai terapi alternatif dapat dipertimbangkan untuk digunakan. Salah satu tanaman di Indonesia yang memiliki potensi secara empiris sebagai antidiabetes adalah bangle (Zingiber cassumunar). Penelitian ini bertujuan untuk menguji aktivitas penghambatan terhadap enzim alfa-glukosidase dari ekstrak etanol rimpang bangle. Hasil IC yang didapatkan dari uji aktivitas penghambatan enzim alfa-glukosidase adalah 98,31 $\mu \mathrm{g} / \mathrm{ml}$. IC $\mathrm{I}_{50}$ akarbosa sebagai pembanding adalah 36,17 $\mu \mathrm{g} / \mathrm{ml}$. Berdasarkan hasil penelitian yang didapatkan, dapat disimpulkan bahwa ekstrak etanol rimpang bangle memiliki potensi yang sangat baik untuk dikembangkan dan dipertimbangkan lebih lanjut sebagai kandidat obat antidiabetes, khususnya untuk mengobati diabetes mellitus tipe II.
\end{abstract}

Kata Kunci: Bangle, Zingiber cassumunar, Alfa-glukosidase, Ekstrak, In vitro

ABSTRACT: Diabetes mellitus is a metabolic disorder characterized by hyperglycemia. One of the various drugs to treat diabetes mellitus, especially type II diabetes mellitus is acarbose. Acarbose could be used in patient with high post-prandial glucose concentration. Mechanism of action of acarbose is inhibition against alphaglucosidase enzyme activity on intestinal. Inhibition on alpha-glucosidase enzyme cause delayed absorption and digestion of glucose. Then, increase of post-prandial glucose concentration could be prevented. Use of synthetic antidiabetic drugs such as acarbose in long-term caused several side effects, especially gastrointestinal problems. Moreover, application of natural products as alternative therapy should be considered to be used. One of Indonesian plants which has potency by empirically as antidiabetes is bangle (Zingiber cassumunar). The objective of this research is to evaluate inhibition activity of ethanol extract of bangle rhizome against alpha-glucosidase enzyme. $I C_{50}$ of bangle rhizome extract which obtained from this research is $98.31 \mu \mathrm{g} / \mathrm{ml} . \mathrm{IC} \mathrm{F}_{50}$ of acarbose is $36.17 \mu \mathrm{g} / \mathrm{ml}$. Based on the result, it can be concluded that ethanol extract of bangle rhizome has great potency for developed and considered as antidiabetic candidate, especially to treat type II diabetes mellitus.

Keywords: Bangle, Zingiber cassumunar, Alpha-glucosidase, Extract, In vitro 


\section{Pendahuluan}

Diabetes mellitus merupakan masalah kesehatan yang sering dijumpai di dunia termasuk di Indonesia. Berdasarkan data yang dihimpun dari International Diabetes Federation (IDF) pada tahun 2015, prevalensi diabetes mellitus terus mengalami peningkatan yang signifikan dan diprediksi meningkat sampai 6,16 miliar pada tahun 2040. Diabetes mellitus adalah sekelompok gangguan metabolik kronis yang ditandai dengan kondisi hiperglikemia karena kerusakan pada produksi insulin, kerja insulin, dan atau keduanya [1]. Diabetes mellitus diklasifikasikan menjadi diabetes mellitus tipe I, diabetes mellitus tipe II, diabetes gestasional, dan diabetes tipe lain. Sebagian besar diabetes mellitus yang terjadi adalah diabetes mellitus tipe II [2].

Upaya-upaya yang dapat dilakukan untuk menangani diabetes mellitus tipe II adalah dengan terapi non-farmakologi dan terapi farmakologi. Terapi non-farmakologi dapat dilakukan dengan cara memodifikasi gaya hidup, sedangkan terapi farmakologi dapat dilakukan dengan cara penggunaan obat-obat anti-diabetik oral. Salah satu obat yang dapat digunakan untuk menangani diabetes mellitus tipe II adalah akarbosa. Akarbosa bekerja dengan cara menghambat kerja enzim alfa-glukosidase. Enzim alfa-glukosidase merupakan enzim penting yang berperan pada hidrolisis karbohidrat menjadi glukosa. Penghambatan pada enzim ini akan memberikan dampak pada penundaan penyerapan glukosa [3]. Penggunaan obat sintetik antidiabetes seperti akarbosa dalam jangka waktu panjang dapat memberikan beberapa efek samping seperti gangguan pada sistem saluran pencernaan seperti mual, muntah, nyeri perut, dan kembung $[4,5]$ sehingga, penggunaan obat bahan alam pada saat ini sebagai terapi alternatif lebih dipertimbangkan karena potensi dan minimalnya efek samping yang diberikan.

Bangle (Zingiber cassumunar Roxb.) merupakan famili Zingiberaceae yang banyak ditemukan di Asia Tenggara, salah satunya di Indonesia. Ba- gian tanaman yang banyak digunakan adalah rimpangnya. Rimpang bangle telah digunakan secara turun-temurun di Indonesia untuk pengobatan beberapa penyakit [6]. Oleh karena itu, penelitian ini bertujuan untuk menguji aktivitas penghambatan enzim alfa-glukosidase dari ekstrak etanol rimpang bangle secara in vitro.

\section{Bahan dan metode}

\subsection{Bahan}

Seluruh bahan yang digunakan dalam penelitian ini berderajat pro analitik. Enzim alfa-glukosidase yang digunakan berasal dari Saccharomyces cerevisae dan $\mathrm{p}$-nitrofenil- $\alpha$-D-glukopiranosid (pNPG) sebagai substrat didapatkan dari SigmaAldrich.

\subsection{Pengumpulan dan determinasi tanaman}

Rimpang bangle (Zingiber cassumunar Roxb.) diperoleh dari daerah Bandung, Jawa Barat. Selanjutnya, rimpang bangle dideterminasi di Laboratorium Taksonomi Tanaman, Departemen Biologi Universitas Padjajaran, Bandung.

\subsection{Proses Ekstraksi}

Rimpang bangle dicuci dengan air sampai bersih, dipotong-potong kecil, dan dilakukan pengecilan ukuran partikel hingga menjadi serbuk. Serbuk rimpang bangle diekstraksi secara maserasi dengan menggunakan pelarut etanol. Filtrat yang didapatkan disaring dan dipekatkan dengan rotary evaporator untuk mendapatkan ekstrak kental. Ekstrak kental yang diperoleh, dituang kedalam cawan penguap dan diletakkan di atas waterbath untuk menghilangkan sisa-sisa pelarut etanol. Ekstrak kering rimpang bangle digunakan untuk pengujian in vitro dan skrining fitokimia ekstrak.

\subsection{Skrining fitokimia ekstrak}

Skrining fitokimia dilakukan untuk mengetahui kandungan kimia yang terdapat pada ekstrak etanol rimpang bangle yang meliputi alkaloid, flavonoid, tannin, saponin, kuinon, dan steroid/ 
triterpenoid.

\subsection{Uji aktivitas enzim alfa-glukosidase}

Aktivitas inhibisi ekstrak etanol rimpang bangle terhadap enzim alfa-glukosidase ditentukan berdasarkan metode yang dilakukan oleh Kim dkk. [7]. Pada penelitian ini enzim alfa-glukosidase yang digunakan berasal dari Saccharomyces cerevisae dan p-nitrofenil- $\alpha$-D-glukopiranosid (pNPG) berfungsi sebagai substrat. $100 \mu \mathrm{l}$ enzim alfa-glukosidase $(1,0 \mathrm{unit} / \mathrm{ml})$ di pre-inkubasi dengan $50 \mu \mathrm{l}$ dari variasi konsentrasi ekstrak selama 10 menit. Variasi konsentrasi ekstrak yang digunakan yaitu 20, 40, 60, 80, dan $100 \mu \mathrm{g} / \mathrm{ml}$. Selanjutnya, $50 \mu \mathrm{l}$ pNPG $(3,0 \mathrm{mM})$ dilarutkan ke dalam $20 \mathrm{mM}$ larutan buffer fosfat dengan $\mathrm{pH}$ 6,9 ditambahkan ke dalam campuran untuk menginisiasi reaksi. Campuran reaksi selanjutnya diikuti dengan proses inkubasi pada suhu $37^{\circ} \mathrm{C}$ selama 20 menit dan reaksi dihentikan dengan penambahan $2 \mathrm{ml} \mathrm{Na}_{2} \mathrm{CO}_{3}(0,1 \mathrm{M})$. Aktivitas enzim alfaglukosidase ditentukan dengan mengukur warna kuning dari para-nitrofenol yang dilepaskan oleh pNPG di panjang gelombang $405 \mathrm{~nm}$. Akarbose digunakan sebagai kontrol positif. Persentase aktivitas inhibisi enzim alfa-glukosidase dihitung dengan persamaan: $\begin{aligned} \text { \% inhibisi }= & \left(\text { Absorbansi }_{\text {kontrol }}-\text { Absorbansi }_{\text {sam- }}\right. \\ & \left.\text { pel } / \text { Absorbansi }_{\text {kontrol }}\right) \times 100\end{aligned}$

\section{Hasil}

\subsection{Skrining fitokimia ekstrak}

Hasil skrining fitokimia ekstrak rimpang bangle mengandung komponen-komponen kimia seperti alkaloid, flavonoid, tanin, kuinon, saponin, dan steroid/triterpenoid.

\subsection{Uji aktivitas enzim alfa-glukosidase}

Inhibitor enzim alfa-glukosidase seperti akarbosa bekerja dengan cara menunda absorpsi glukosa di dalam usus sehingga dapat mencegah kenaikan level gula darah post-prandial. Oleh karena itu, enzim alfa-glukosidase menjadi salah satu enzim target untuk pengobatan penyakit diabetes mellitus tipe II. Selanjutnya, upaya-upaya pencarian dan pengembangan kandidat antidiabetes dari bahan alam sebagai upaya alternatif terus dieksplorasi lebih lanjut. Salah satu tanaman yang berpotensi baik untuk dikembangkan sebagai kandidat obat antidiabetes di Indonesia adalah rimpang bangle.

Tabel 1 menunjukkan hasil uji aktivitas inhibisi dari ekstrak etanol rimpang bangle terhadap

Tabel 1. Aktivitas inhibisi ekstrak etanol rimpang bangle dan akarbosa terhadap enzim alfa-glukosidase

\begin{tabular}{llll}
\hline Sampel & Konsentrasi $(\boldsymbol{\mu g} / \mathbf{m l})$ & \% Inhibisi $\mathbf{~ S D}$ & $\mathbf{I C}_{\mathbf{5 0}}(\boldsymbol{\mu g} / \mathbf{m l})$ \\
\hline Ekstrak Etanol Rimpang Bangle & 20 & $43,21 \pm 1,00$ & 98,31 \\
& 40 & $44,11 \pm 0,91$ & \\
& 60 & $46,01 \pm 0,95$ & \\
& 80 & $48,56 \pm 0,88$ & \\
\hline Akarbosa & 100 & $50,28 \pm 0,87$ & 36,17 \\
& 20 & $40,22 \pm 0,50$ & \\
& 40 & $52,40 \pm 0,52$ & \\
& 60 & $64,13 \pm 0,17$ & \\
\hline
\end{tabular}

enzim alfa-glukosidase secara in vitro. Nilai $\mathrm{IC}_{50}$ yang didapatkan dari aktivitas inhibisi ekstrak 
rimpang bangle terhadap enzim alfa-glukosidase adalah 98,31 $\mu \mathrm{g} / \mathrm{ml}$. Pada penelitian ini, obat standar yang digunakan sebagai kontrol positif adalah akarbosa. Nilai IC $_{50}$ dari akarbosa adalah 36,17 $\mu \mathrm{g} / \mathrm{ml}$. Berdasarkan hasil penelitian, ekstrak etanol rimpang bangle memiliki kemampuan yang baik untuk dapat menghambat aktivitas enzim alfa-glukosidase secara in vitro. Kandungan kimia tanaman seperti adanya alkaloid, flavonoid, tannin, saponin, kuinon, dan steroid/triterpenoid kemungkinan memiliki tanggungjawab terhadap aktivitas penghambatan enzim alfa-glukosidase $[8,9]$. Hal ini berbeda dengan penelitian sebelumnya yang menunjukkan bahwa ekstrak metanol dari rimpang bangle justru memiliki kemampuan yang kecil dalam menghambat aktivitas enzim alfa-glukosidase walaupun dengan metode ekstraksi yang sama, yaitu metode maserasi [10]. Perbedaan pelarut dalam hal ini juga menentukan penarikan komponen kimiawi dari bangle. Selain perbedaan pelarut, adanya modifikasi-modifikasi kecil dalam komponen pengujian in vitro turut menentukan aktivitas penghambatannya.

\section{Kesimpulan}

Berdasarkan hasil penelitian yang didapatkan melalui pengujian aktivitas inhibisi enzim alfaglukosidase, dapat disimpulkan bahwa ekstrak etanol rimpang bangle memiliki potensi yang baik untuk dapat dikembangkan dan dipertimbangkan sebagai kandidat obat antidiabetes, khususnya diabetes mellitus tipe II.

\section{Ucapan terimakasih}

Penelitian ini sebagian didanai oleh Hibah Riset Unggulan yang diberikan oleh Pusat Penelitian dan Pengabdian Masyarakat Sekolah Tinggi Farmasi Bandung (P3M STFB).

\section{Daftar pustaka}

1. Watcharachaisoponsiri T, Sornchan P, Charoen- kiatkul S, Suttisansanee U. The $\alpha$-glucosidase and $\alpha$-amylase inhibitory activity from different chili pepper extracts. Int Food Res J. 2016;23(4):143945.

2. Baynes HW. Classification, pathophysiology, diagnosis, and management of diabetes mellitus. Diabetes Metab. 2015;6(5):1-9.

3. Khatri DK, Juvekar AR. $\alpha$-glucosidase and $\alpha$-amylase inhibitory activity of Indigofera cordifolia seeds and leaves extract. Int J Pharm Pharm Sci. 2014;6(11):152-5.

4. DiNicolantanio JJ, Bhutani J, O'Keefe JH. Acarbose: safe and effective for lowering postprandial hyperglycemia and improving cardiovascular outcomes. Open Heart. 2015;2(1):1-13.

5. Nakhaee A, Sanjari M. Evaluation of effect of acarbose consumption on weight losing in nondiabetic overweight or obese patients in Kerman. J Res Med Sci. 2013;18(5):391-4.

6. Singh CB, Manglembi N, Swapana N, Chanu SB. Ethnobotany, phytochemistry, and pharmacology of Zingiber cassumunar Roxb. J Pharmacogn Phytochem. 2015;4(1):1-4.

7. Kim YM, Jeong YK, Wang MH, Lee WY, Rhee HI. Inhibitory effects of pine bark extract on alpha-glucosidase activity and postprandial hyperglycemia. Nutrition. 2005;21:756-61.

8. Hafeez K, Andleeb S, Ghousa T, Mustafa RG, Naseer A, Shafique I, Akhter K. Phytochemical screening, alpha-glucosidase inhibition, antibacterial and antioxidant potential of Ajuga bracteosa extracts. Current Pharmaceutical Biotechnology. 2017;18(4):336-42.

9. Elya B, Handayani R, Sauriasari R, Azizahwati, Hasyyati US, Permana IT, Permatasari YI. Antidiabetic activity and phytochemical screening of extracts from Indonesian plants by inhibition of alpha amylase, alpha glucosidase and dipeptidyl peptidase IV. Pakistan Journal of Biological Sciences. 2015;18(6):279-84.

10. Indrianingsih $A W$, Tachibana $S$, Itoh $K$. In vitro evaluation of antioxidant and $\alpha$-glucosidase inhibitory assay of several tropical and subtropical plants. Procedia Environmental Sciences. 2015;28:639-48. 